\title{
How do the Banking Systems of Vietnam, China and India Fare?
}

\author{
Thanh Pham Thien Nguyen \\ University of Economics Ho Chi Minh city \\ E-mail: thanh.nguyen8@griffithuni.edu.au
}

Received: Sep. 14, 2015 Accepted: Oct. 29, 2015 Published: December 1, 2015

doi:10.5296/ajfa.v7i2.8296 URL: http://dx.doi.org/10.5296/ajfa.v7i2.8296

\begin{abstract}
Given that Vietnam, China and India are among the few remaining banking systems which have central bank dependence, state dominance, regulatory restrictions and gradual reforms towards liberalisation, this study examines cost, revenue and profit efficiency and stability of these banking systems. Using DEA Window Analysis, the study found that these banking systems achieved high efficiency levels, with generally increasing efficiency from 1995 to 2011. Cost efficiency was equally driven by technical and allocative efficiencies; revenue efficiency was driven by interest income efficiency more than by non-interest income efficiency; and profit efficiency was equally driven by cost and revenue efficiencies. Furthermore, state banks were found to be more efficient than private banks, but this efficiency gap declined over time. Compared to private banks, state banks appear to have been better at coping with the Asian financial crisis (AFC), but worse at facing the Global financial crisis (GFC). However, banking systems of Vietnam and China were slightly hit by the AFC, while China and India were slightly hit by the GFC.
\end{abstract}

Keywords: efficiency, crises, state banks, DEA Window Analysis

JEL Classification: G21, G01, C61 


\section{Introduction}

The banking systems of Vietnam, China and India are among the few remaining regulated and state-dominated systems in Asia, which started with a regulated and state-dominated system, but then moved towards a deregulated and private-dominated system by later liberalisation and privatization These countries initiated gradual reforms towards liberalization from the $1990 \mathrm{~s}$, but the central bank is not independent from the government. Moreover, restrictions on interest rate, credit allocation, credit growth and foreign investors still exist. In these countries, state banks take up the largest market share, followed by private banks, then foreign banks. Notably, India's reforms have generally been more comprehensive and have been implemented at a faster pace than those of Vietnam and China. These give rise to interesting research questions: How efficient and resilient have the regulated and state-dominated banking systems of Vietnam, China and India been over the last two decades?

Efficiency is measured by cost, revenue and profit efficiency. Data Envelopment Analysis (DEA)with a Window Analysis approach introduced by Charnes et al. (1984)was employed to estimate efficiency scores of individual banks. As this method uses moving average analogues, it can reduce the effects of banking technology progress over time when capturing the efficiency trend. It is also appropriate for our small-size dataset. To have a robust check of the findings on the banking-system efficiency trend and efficiency gap between state and private banks which were obtained from calculated raw efficiency scores, Tobit regression is conducted in the second stage. Annual data for the period 1995-2011 was utilised because it covers most of the significant changes in the three banking systems including recapitalization and privatization of state banks, financial liberalization, WTO entry, regulatory changes, and the Asian financial crisis (AFC) in 1997 and Global financial crisis (GFC) in 2007.

The study found that regulated and state-dominated banking systems of Vietnam, China and India achieved high efficiency levels, with generally increasing efficiency from 1995 to 2011. Cost efficiency was equally driven by technical and allocative efficiencies; revenue efficiency was driven by interest income efficiency more than by non-interest income efficiency; and profit efficiency was equally driven by cost and revenue efficiencies. Furthermore, state banks were found to be more efficient than private banks, but this efficiency gap declined over time. Compared to private banks, state banks appear to have been better at coping with the Asian financial crisis (AFC), but worse at facing the Global financial crisis (GFC). However, banking systems of Vietnam and China were slightly hit by the AFC, while China and India were slightly hit by the GFC.

This study makes several contributions. Firstly, although there are a large number of studies on bank efficiency either across or within countries over the last two decades, this is the first study of differences and similarities in the efficiency of banks across Vietnam, China and India. Secondly, this is the first study measuring bank efficiency by simultaneously considering the three most important economic aspects: cost, revenue and profit efficiencies. Thirdly, this study provides a comprehensive background of these banking systems in regards to the banking structure, state dominance, regulatory restrictions and gradual reforms towards 
liberalisation in recent decades. Fourthly, the findings of this study will provide insights into the merits and demerits of a regulated and state-dominated banking environment; thereby, offering some lessons for other countries' future reform agenda. Lastly, this study makes advances in methodology by combining DEA Three-Year Window Analysis and size-adjusted efficiency measures to characterise the banking system and banking-type efficiency.

This study is organized as follows. Section 2 provides a background of the regulated and state-dominated banking systems of Vietnam, China and India. Section 3 shows the DEA Window Analysis and data sample used for the assessment of bank efficiency. Section 4 analyses empirical findings, followed by section 5 which provides concluding remarks.

\section{Background of the regulated and state-dominated banking systems of Vietnam, China and India}

The banking systems of Vietnam, China and India have similarities in commercial banking such as bank-type structure, state dominance,regulatory restrictions and reforms towards liberalisation.In Vietnam and India, the banking system is monitored and regulated by their central banks (State Bank of Vietnam and Reserve Bank of India, respectively), whilethere are two regulatory institutions in the banking system of China: the central bank (the People's Bank of China)and the China Banking Regulatory Commission. In Vietnam and India, moreover, commercial banks are divided into three categories based on ownership criteria: state banks (above 50\% government ownership; called public banks in India), private banks (above 50\% private ownership; called joint-stock banks in Vietnam), and joint-venture and foreign banks (at least 49\% foreign ownership). However, there is one more category China: local banks(provincial or municipal governments are major stockholders and their operation limited to one city and the surrounding area).

Since the 1990s the governments of Vietnam, China and India have started making gradual banking reforms towards deregulation, but the governmentstill wields the power to beable to significantlyintervene in the banking system via state-owned banks and regulatory restrictions. Table 1 highlights that though these banking systems are dominated by state banks, there seems to be tough competition between state and private banks, as the former gradually lost their marketshare to the latter. However, state banks were partially privatized (from1991 in India, 2005 in China and 2007 in Vietnam), because they were considered to store significant non-performing loans, but to enable intervention the government still retains the controlling stake in these privatized banks.

In these countries, governments hold various powers to intervene. Theycan,because of central bank dependence, intervene in the operation of commercial banks, for instance, on interest rates, credit allocation, credit growth and foreign investors. The Vietnamese government,for example, sets upper limits on mobilising and lending interest rates and loans distributed to securities and real estate. It encourages banks to give loans to sectors such as agricultural, rural, export production, support industries, and small and medium enterprises. It alsocontrols the credit growth of individual banks based on their performance as well as the whole banking system based on the country's economic performance. However, in order to improve 
competition the Vietnamese government has reduced barriers to foreign banks; however, foreign banks were more restricted in entry, activity and opening branches than domestic state and private banks. For instance, transactions of foreign banks were limited to only foreign currency in 1991-1994. These restrictions were lifted in 1994.Foreign banks could now gather local currency denominated deposits which did not exceed 20 per cent of their charter capital and from households and businesses with no existing credit relationships. From 2010, foreign banks have been allowed to operate with fewer restrictions and at level with domestic banks as per commitment to the World Trade Organisation (WTO). Further, domestic banks have been allowed to draw foreign investment up to $30 \%$.

In China, prior to 1997, the government fixed deposits and lending interest rates, and required banks to provide loans to state-owned enterprises at lower fixed interest rates than those extended to other types of enterprises. In the following years, interest rates on loans and deposits were gradually liberalized, but the central bank still set benchmark interest rates for RMB-denominated deposits and loans. That is, banks were allowed to offer interest rates within a band above and below the benchmark rates. Also, the central bank stopped allocating credit quotas to individual banks but continued to set overall credit growth targets for the year. An additional observation is that the Chinese government has been very conservative in allowing foreign bank entry. From 2003, for instance, foreign banks were allowed to expand RMB business from the four major cities of Shanghai, Shenzhen, Tianjin and Dalian to the rest of the country. From 2007, RMB business activity was extended from foreign enterprises and individuals to cover domestic firms and residents. Quantitative restrictions on RMB liabilities were lifted, various restrictions on branch development were removed, and capital requirements were set in equality with domestic banks. From 2003, foreign investors have been permitted to hold minority stakes in a domestic bankup to $25 \%$.

The Indian banking reform program can be divided into two stages: 1991-1997 and 1998 onwards. The first stage relates to structural deregulation aimed at promoting competition. This stage was characterised by the liberalisation of interest rates on deposits and lending, the removal of restrictions on entry and on private ownership, and an increase in the range of permissible activities. However, banks were not free to determine the interest rates for all loans and term deposits below INR200,000. The second stage aimed at strengthening financial stability. The whole reform process was aimed at creating a level playing field among different bank types through regulatory policies relating to interest rates, prudential norms, and reserve requirements applied uniformly across bank groups. Nonetheless, priority sector credit requirements remain in place, with different targets for domestic and foreign banks (lending portion of $40 \%$ for domestic banks and $32 \%$ for foreign banks). Although the targets have not changed during the reform period, the cost of this directed lending practice has been gradually reduced by expanding the definition of priority sector lending and liberalizing lending interest rates on advances over INR200,000. Unlike Vietnam and China, banking reform in India has not involved large scale privatization. The approach, instead, first involved recapitalization of banks from government resources to bring them up to appropriate capitalization standards. Second, instead of privatization, increase in capitalization has been done through diversification of ownership to private investors up to a limit of $49 \%$, thereby 
keeping majority ownership and control with the government. Also, limit on foreign investment in a domestic bank increased from 40\% in 1998 to $49 \%$ in 2001.

In summary, the three banking systems -Vietnam, China and India - are regulated and state-dominated.Governments in these countriesare still able to wield significant influence over the operations of commercial banks via state banks and regulatory restrictions although theyhave implemented gradual banking reforms towards deregulationsince the 1990s. Nevertheless, it appears that India's reforms are generally more comprehensive and implemented at a faster pace than those of Vietnam and China, as foreign banks' activity and foreign stakes in a domestic bank in India are the least restricted.

Table 1. Distribution of deposits by bank types (\%)

\begin{tabular}{|c|c|c|c|c|c|c|c|c|c|c|c|c|}
\hline Country & Bank type & 2000 & 2001 & 2002 & 2003 & 2004 & 2005 & 2006 & 2007 & 2008 & 2009 & 2010 \\
\hline \multirow{3}{*}{ Vietnam } & State-owned banks & 78.4 & 80.8 & 80.5 & 79.5 & 78.1 & 78.6 & 70.0 & 58.0 & 56.1 & 49.7 & 39.7 \\
\hline & Joint-stock banks & 11.3 & 9.2 & 10.1 & 11.2 & 13.2 & 14.3 & 22.0 & 29.0 & 35.9 & 42.8 & 51.4 \\
\hline & $\begin{array}{l}\text { Foreign and joint-venture } \\
\text { banks }\end{array}$ & 10.3 & 10.0 & 9.4 & 9.3 & 9.7 & 7.1 & 8.0 & 13.0 & 8.1 & 7.5 & 8.9 \\
\hline \multirow{4}{*}{ China } & Equitized banks & & & & 76.8 & 75.1 & 74.3 & 72.7 & 70.6 & 69.5 & 68.5 & 65.7 \\
\hline & Joint-stock banks & & & & 14.3 & 15.4 & 16.1 & 16.7 & 18.2 & 19.0 & 20.0 & 21.0 \\
\hline & City commercial banks & & & & 7.0 & 7.2 & 7.2 & 7.9 & 8.3 & 8.8 & 9.4 & 11.0 \\
\hline & Foreign and joint-venture banks & & & & 1.9 & 2.3 & 2.4 & 2.7 & 3.0 & 2.7 & 2.1 & 2.3 \\
\hline \multirow{3}{*}{ India } & Public banks & 81.7 & 78.1 & 77.7 & 76.5 & 76.9 & 74.4 & 72.9 & 73.5 & 75.8 & 76.6 & 76.9 \\
\hline & Private banks & 12.8 & 16.7 & 17.6 & 18.5 & 18.6 & 20.1 & 21.3 & 20.9 & 18.8 & 18.3 & 18.6 \\
\hline & $\begin{array}{l}\text { Foreign and joint-venture } \\
\text { banks }\end{array}$ & 5.5 & 5.2 & 4.7 & 5.0 & 4.5 & 5.5 & 5.8 & 5.7 & 5.4 & 5.2 & 4.5 \\
\hline
\end{tabular}

Source: authors' calculation from central banks' reports

\section{Methodology and data}

\subsection{Methodology}

This study first employed DEA Window Analysis to estimate cost, revenue and profit efficiencies of individual banks. These efficiency scores were then weighted by total funding to characterize the overall efficiency levels and trends of the banking system as well as its bank types over the period 1995-2011. This study also employed Tobit regression as a robust check of the findings on the banking-system efficiency trend and efficiency gap between state and private banks, which were obtained from calculated raw efficiency scores. This study also examines the drivers of these efficiencies by breaking cost efficiency into input-oriented technical efficiency and input-allocative efficiency, and revenue efficiency into interest-revenue efficiency and non-interest revenue efficiency. This study selects inputs and outputs under intermediation approach and uses data from FITCH. 


\subsubsection{DEA models and Window Analysis}

The two most widely-used frontier techniques are Stochastic Frontier Analysis (SFA), and Data Envelopment Analysis (DEA). SFA, a parametric method, requires a large dataset to give reliable results while DEA, a non-parametric technique, can provide information on the peer group. DEA was selected in this study since some years of our data have less than 15 banks and information on peer group was very useful for managerial purposes. Moreover, we estimated these efficiencies under variable return to scale (VRS) assumption to rule out any impact of scale inefficiency in the overall analysis, because the dataset included numeric values with a large difference in magnitude.

Cost/revenue/profit efficiency reflects how close a bank's actual cost/revenue/profit is to what the best-practiced bank's cost/revenue/profit would be. To assess the efficiency trend over the years using DEA, the mean efficiencies of individual years can be estimated by forming corresponding individual frontiers or by forming only one frontier over data points of the analysis period. For the former, it is difficult to identify whether the progress or regression in efficiency over the years is a result of efficiency change or technological change. For the latter, efficiency estimates assume an unchanged production technology, an assumption that is difficult to hold in the long period. DEA Window Analysis introduced by Charnes et al. (1984) and DEA Malmquist Index which was first suggested by Malmquist (1953) can minimize the effect of production technology progress when capturing the efficiency trend over time.

DEA Window Analysis assesses the efficiency change over time by using a moving average analogue. This technique treats a DMU in one year independently of the next. DEA Malmquist Index measures the total factor productivity change between two data points by calculating the ratio of the distance of each data point relative to a common technology. Of the two, the former has the advantage of being able to increase the number of observations of the data sample, so it can improve the degree of freedom, resulting in more reliable efficiency estimates (Avkiran, 2004). A rough rule of thumb to have sufficient efficiency discrimination among DMUs is to have a number of DMUs equal to or greater than 3 times of total number of inputs and outputs (William Wager Cooper et al., 2007). Our study has 3 inputs and 2 outputs, so the desirable number of DMUs is at least 15. Since some years in our dataset have less than 15 banks, DEA Window Analysis was selected to estimate banking efficiency levels and trends.

In the banking systems of Vietnam, China and India, there is a big difference in size between state and private banks as well as among private banks. Unweighted efficiency average, therefore, may not necessarily be a good way to characterize the efficiency of the banking industry and its bank types, since small banks may distort these overall efficiencies and people tend to emphasize large banks. We, instead, use weighted efficiency measure introduced by Zhu (2000), with the weights of individual banks for individual years calculated based on total funding criterion. Efficiency estimate is expressed as a number between 0 and 1, where a bank with an estimate of less than 1 is considered inefficient. 


\section{1) Macrothink}

Assuming that we have $\mathrm{n}$ banks $(\mathrm{i}=1, \ldots, \mathrm{n})$ that use a vector of $\mathrm{m}$ inputs $x_{i}=\left(x_{i 1}, \ldots, x_{i m}\right)$ for which they pay prices $c_{i}=\left(c_{i 1}, \ldots, c_{i m}\right)$ to produce a vector of $\mathrm{s}$ outputs $y_{i}=$ $\left(y_{i 1}, \ldots, y_{i s}\right)$ which are sold at price $r_{i}=\left(r_{i 1}, \ldots, r_{i s}\right)$. DEA models and Window Analysis to estimate bank efficiency are as follows:

\section{Cost efficiency (CE) model}

The widely-used cost efficiency model for estimating the cost efficiency of bank $\mathrm{j}$ can be expressed in linear programming as follows:

$$
\operatorname{Min} \sum_{m} c_{j m} x_{j m}
$$

Subject to

$$
\begin{gathered}
x_{j m} \geq \sum_{i} x_{i m} \lambda_{i} \forall m \\
y_{j s} \leq \sum_{i} y_{i s} \lambda_{i} \quad \forall s \\
\sum_{i=1}^{n} \lambda_{i}=1 \\
\lambda \geq 0
\end{gathered}
$$

The solution to this model is the optimal input demand vector $x_{j}^{*}=\left(x_{j 1}^{*} \ldots \ldots, x_{j m}^{*}\right)$ in the production possibility, which minimizes costs with the given input prices $\mathrm{c}$, and is obtained from a linear combination of banks that produces at least as much output as bank $\mathrm{j}$ does, using the same or less amount of input. This hypothetical bank then would have an optimal $\operatorname{cost} C_{j}^{*}=\sum_{m} c_{j m} x_{j m}^{*}$ which, by definition, would be less than or equal to that of bank $\mathrm{j}$ $\left(C_{j}=\sum_{m} c_{j m} x_{j m}\right)$. The cost efficiency of bank $\mathrm{j}\left(\mathrm{CE}_{\mathrm{j}}\right)$ is defined as follows:

$$
C E_{j}=\frac{C_{j}^{*}}{C_{j}}=\frac{\sum_{m} c_{j m} x_{j m}^{*}}{\sum_{m} c_{j m} x_{j m}}
$$

To examine the drivers of cost efficiency, input-oriented technical efficiency (TE) of bank j, where the inputs are minimized and the outputs are kept at their current level, was initially estimated under the model introduced by Banker et al. (1984):

$\operatorname{Min} \theta$

Subject to 


$$
\begin{gathered}
\theta x_{j m} \geq \sum_{i} x_{i m} \lambda_{i} \quad \forall m \\
y_{j s} \leq \sum_{i} y_{i s} \lambda_{i} \quad \forall s \\
\sum_{i=1}^{n} \lambda_{i}=1 \\
\lambda \geq 0
\end{gathered}
$$

Then, input-allocative efficiency (AE), where the cost can be minimized by combining inputs in an optimal way while unchanging the current outputs, was computed based on the formula: $\mathrm{AE}=\mathrm{CE} / \mathrm{TE}$.

\section{Revenue efficiency (RE) model}

Revenue efficiency model introduced by William W Cooper and Seiford (2000)was employed to measure revenue efficiency for bank $\mathrm{j}$ as follows:

$$
\operatorname{Max} \sum_{s} r_{j s} y_{j s}
$$

Subject to

$$
\begin{gathered}
x_{j m} \geq \sum_{i} x_{i m} \lambda_{i} \quad \forall m \\
y_{j s} \leq \sum_{i} y_{i s} \lambda_{i} \quad \forall s \\
\sum_{i=1}^{n} \lambda_{i}=1 \\
\lambda \geq 0
\end{gathered}
$$

The solution to this model is the optimal output supply vector $y_{j}^{*}=\left(y_{j 1}^{*} \ldots \ldots, y_{j s}^{*}\right)$ in the production possibility, which maximizes revenues with the given output prices $r$. This hypothetical bank then would have optimal revenue $R_{j}^{*}=\sum_{s} r_{j s} y_{j s}^{*}$ which, by definition, would be higher or equal to that of bank $\mathrm{j}\left(R_{j}=\sum_{s} r_{j s} y_{j s}\right)$. The revenue efficiency of bank $\mathrm{j}$ $\left(R E_{j}\right)$ is defined as follows: 


$$
R E_{j}=\frac{R_{j}}{R_{j}^{*}}=\frac{\sum_{s} r_{j s} y_{j s}}{\sum_{s} r_{j s} y_{j s}^{*}}
$$

To examine the drivers of revenue efficiency, we first separated the overall revenue into interest revenue and non-interest revenue, and then estimated interest-revenue efficiency and non-interest revenue efficiency.

\section{Profit efficiency (PE) model}

The profit efficiency model developed by Färe and Grosskopf (1997) and Färe et al. (2004)was employed to measure profit efficiency for bank $\mathrm{j}$ as follows:

$$
\operatorname{Max} \sum_{s} r_{j s} y_{j s}-\sum_{m} c_{j m} x_{j m}
$$

Subject to

$$
\begin{gathered}
x_{j m} \geq \sum_{i} x_{i m} \lambda_{i} \quad \forall m \\
y_{j s} \leq \sum_{i} y_{i s} \lambda_{i} \quad \forall s \\
\sum_{i=1}^{n} \lambda_{i}=1 \\
\lambda \geq 0
\end{gathered}
$$

The solution to this model is a combination of the optimal output supply vector $y_{j}^{*}=$ $\left(y_{j 1}^{*} \ldots \ldots, y_{j s}^{*}\right)$ and the optimal input demand vector $x_{j}^{*}=\left(x_{j 1}^{*} \ldots \ldots, x_{j m}^{*}\right)$ in the production possibility set that maximizes the profits with the given output prices $r$ and input prices $\mathrm{c}$, and is obtained from a linear combination of banks that produces at least as much outputs as bank $\mathrm{j}$ does, using the same or less amount of inputs. This hypothetical bank then would have an optimal profit $P_{j}^{*}=\sum_{s} r_{j s} y_{j s}^{*}-\sum_{m} c_{j m} x_{j m}^{*}$ which, by definition, would be higher than or equal to the actual profit of bank $\mathrm{j}\left(P_{j}=\sum_{s} r_{j s} y_{j s}-\sum_{p} c_{j m} x_{j m}\right)$. The profit efficiency for bank $\mathrm{j}\left(\mathrm{PE}_{\mathrm{j}}\right)$ then can be measured as follows:

$$
P E_{j}=\frac{P_{j}}{P_{j}^{*}}=\frac{\sum_{s} r_{j s} y_{j s}-\sum_{m} c_{j m} x_{j m}}{\sum_{s} r_{j s} y_{j s}^{*}-\sum_{m} c_{j m} x_{j m}^{*}}
$$




\section{Window Analysis}

DEA Window Analysis proposed by Charnes et al. (1984) and Charnes and Cooper (1984)was employed to assess the efficiency trend over the 1995-2011 period. We chose a three-year window since three years is appropriate for common frontier and moving average analogue (Table 2). The principle of forming 15 windows over 1995-2011 is that when a new period is introduced into the window, the earliest year is dropped. Thus, the first window includes the first three years of the analysis period-1995, 1996 and 1997. In the second window, year 1995 was excluded and year 1998 included and so on. Since DEA Window Analysis treats a DMU independently across the entire period, 15 three-year windows considerably increases the number of observations of the sample, providing a greater degree of freedom and producing a more reliable result (Avkiran, 2004).

As illustrated in Table 2, the efficiency trend of each DMU (bank) can be evaluated over 17 years (averaging from the column view) or over 15 windows (averaging from row view).However, as we are more interested in the efficiency change over the years, we present the result of the efficiency trend by calculating from column view.

Table 2. 15, three-year window breakdown table over the period 1995-2011

\begin{tabular}{|c|c|c|c|c|c|c|c|c|c|c|c|c|c|c|c|c|c|}
\hline Window 1 & 1995 & 1996 & 1997 & & & & & & & & & & & & & & \\
\hline Window 2 & & 1996 & 1997 & 1998 & & & & & & & & & & & & & \\
\hline Window 3 & & & 1997 & 1998 & 1999 & & & & & & & & & & & & \\
\hline Window 4 & & & & 1998 & 1999 & 2000 & & & & & & & & & & & \\
\hline Window 5 & & & & & 1999 & 2000 & 2001 & & & & & & & & & & \\
\hline Window 6 & & & & & & 2000 & 2001 & 2002 & & & & & & & & & \\
\hline Window 7 & & & & & & & 2001 & 2002 & 2003 & & & & & & & & \\
\hline Window 8 & & & & & & & & 2002 & 2003 & 2004 & & & & & & & \\
\hline Window 9 & & & & & & & & & 2003 & 2004 & 2005 & & & & & & \\
\hline Window 10 & & & & & & & & & & 2004 & 2005 & 2006 & & & & & \\
\hline Window 11 & & & & & & & & & & & 2005 & 2006 & 2007 & & & & \\
\hline Window 12 & & & & & & & & & & & & 2006 & 2007 & 2008 & & & \\
\hline Window 13 & & & & & & & & & & & & & 2007 & 2008 & 2009 & & \\
\hline Window 14 & & & & & & & & & & & & & & 2008 & 2009 & 2010 & \\
\hline Window 15 & & & & & & & & & & & & & & & 2009 & 2010 & 2011 \\
\hline
\end{tabular}

\subsubsection{Input-output specification}

To estimate efficiency scores, various input-output specifications have also been proposed under intermediation and production approach, with each likely to produce a slightly different result (Drake et al., 2009; Moffat \& Valadkhani, 2011). While all approaches have particular merits and demerits, the intermediation approach seems to be preferred as banks primarily intermediate funds between savers and investors (Altunbas et al., 2001; Koetter, 2006; Maudos et al., 2002).Accordingly, this study employs intermediation approach, which commonly specifies inputs as total funding, physical assets and the number of employees, with corresponding prices as unit interest cost of funding, unit other operating costs of physical assets, and unit price of employees. Similarly, outputs include net loans and other earning assets, with corresponding prices as unit interest income of net loans and unit non-interest operating income of other earning assets. We are not able to obtain data on the number of employees, thus we respectively use personnel expenses and 1 as proxies for number of 
employees and the corresponding price to comply with the objectives of cost-minimisation of cost efficiency model and profit-maximisation of profit efficiency model (Table 4).

\subsection{Data}

Our sample is an unbalanced panel consisting of 30 Vietnamese banks, 17 Chinese banks and 52 Indian banks over the period of 1995-2011 (Table 3). The 17-year period (1995-2011) was selected because it covers most of the significant changes in the three banking systems, including recapitalization and privatization of state banks, financial liberalization, WTO entry, regulatory changes, and the AFC 1997 and GFC 2007. All data were obtained mainly from FITCH, accounting for over $70 \%$ of all banking assets. Some of the missing values were backfilled from audited annual reports. We did not include foreign banks, since their scope and location of business are much more restricted than state and private banks, their business is within the parent banks' strategy, and some were just recently established. We also did not include city commercial banks in China, because they are only allowed to operate in one city while state and private banks operate on a national scale. Thus, our dataset includes only state and private banks to ensure data homogeneity. Table 3 shows that there are considerably fewer state banks than private banks in Vietnam and China, but slightly more state banks than private banks in India.

Table 3. Data sample over the period 1995-2011

\begin{tabular}{|c|c|c|c|c|c|c|c|c|c|c|c|c|c|c|c|c|c|c|}
\hline Country & & 1995 & 1996 & 997 & 1998 & 1999 & 2000 & 2001 & 2002 & 2003 & 2004 & 2005 & 2006 & 2007 & 2008 & 2009 & 20102 & 2011 \\
\hline & Total & 11 & 13 & 13 & 14 & 16 & 16 & 18 & 19 & 21 & 23 & 24 & 29 & 30 & 30 & 30 & 30 & 28 \\
\hline Vietnam & State banks & 4 & 4 & 4 & 4 & 5 & 5 & 5 & 5 & 5 & 5 & 5 & 5 & 5 & 5 & 5 & 5 & 5 \\
\hline & Joint-stock banks & 7 & 9 & 9 & 10 & 11 & 11 & 13 & 14 & 16 & 18 & 19 & 24 & 25 & 25 & 25 & 25 & 23 \\
\hline \multirow{3}{*}{ China } & Total & 12 & 14 & 14 & 14 & 14 & 14 & 14 & 14 & 14 & 15 & 16 & 17 & 17 & 17 & 17 & 17 & 17 \\
\hline & Equitized banks & 4 & 5 & 5 & 5 & 5 & 5 & 5 & 5 & 5 & 5 & 5 & 5 & 5 & 5 & 5 & 5 & 5 \\
\hline & Joint-stock banks & 8 & 9 & 9 & 9 & 9 & 9 & 9 & 9 & 9 & 10 & 11 & 12 & 12 & 12 & 12 & 12 & 12 \\
\hline \multirow{3}{*}{ India } & Total & 50 & 50 & 50 & 50 & 51 & 51 & 52 & 51 & 50 & 50 & 51 & 49 & 49 & 47 & 47 & 45 & 44 \\
\hline & Public banks & 28 & 28 & 28 & 28 & 28 & 28 & 28 & 28 & 27 & 27 & 28 & 28 & 28 & 27 & 27 & 26 & 26 \\
\hline & Private banks & 22 & 22 & 22 & 22 & 23 & 23 & 24 & 23 & 23 & 23 & 23 & 21 & 21 & 20 & 20 & 19 & 18 \\
\hline
\end{tabular}

Source: FITCH

Input and output data were adjusted by the GDP deflator, with 1994, 2000 and 2004 as the respective base years of Vietnam, China and India. Table 4 shows descriptive statistics of the inputs, outputs and prices used for estimating efficiencies in the banking system of Vietnam, China and Indiain 1996 and 2010. It can be seen that total funding, net loans and other earning assets of the whole banking system and its bank types expanded over the years. Of the two bank types, private banks are much smaller in size, but expanded at a higher speed over the study period than state banks. There was also a wide dispersion in size among banks of each bank type. Banks also suffered a considerable increase in costs for employees. Mobilizing and lending interest rate and operating cost per unit varied from year to year. Weighted data calculated for individual years based on total funding criterion is available from the corresponding author. 


\section{I Macrothink}

Table 4. Inputs, outputs and prices in 1996 and 2010 per bank/year deflated by GDP deflator; standard deviations in brackets; X1, X2, X3, Y1, Y2 in million USD; C1, C2, R1, R2 in percentage

\begin{tabular}{|c|c|c|c|c|c|c|c|c|c|c|c|c|c|c|c|c|c|}
\hline \multirow{4}{*}{$\begin{array}{l}\text { Input } \\
\text { Output } \\
\text { Price } \\
\mathrm{X} 1\end{array}$} & \multicolumn{6}{|c|}{ Vietnam } & \multicolumn{5}{|c|}{ China } & \multicolumn{6}{|c|}{ India } \\
\hline & \multicolumn{3}{|c|}{1996} & \multicolumn{3}{|c|}{2010} & \multirow{2}{*}{\multicolumn{3}{|c|}{1996}} & & 2010 & \multicolumn{3}{|c|}{1996} & \multicolumn{3}{|c|}{2010} \\
\hline & All & State & Private & All & State & Private & & & & & Equitized Private & All & Public & Private & All & Public & Private \\
\hline & 432 & 1259 & 64 & 1364 & 4175 & 802 & 78477 & 209575 & 5645 & 351261 & 911064118010 & 4416 & 7378 & 645 & 18637 & 26260 & 8347 \\
\hline & (595) & $(302)$ & (44) & (1637) & (2234) & (657) & $(125278)$ & (132515) & (3805) & (411394) & (726280) (75268) & $(7701)$ & (9313) & (534) & $(30662)$ & (37236) & (13593) \\
\hline \multirow[t]{2}{*}{$\mathrm{X} 2$} & 6.9 & 18.7 & 1.6 & 9.2 & 26.1 & 5.8 & 1333 & 3575 & 88 & 3236 & 9412 & 77 & 119 & 22 & 165 & 220 & 91 \\
\hline & $(9.2)$ & (8.1) & (1.4) & (11.0) & (16.6) & (5.3) & (2027) & (1889) & (76) & (4528) & (3724) & (102) & (119) & (26) & (201) & (217) & (153) \\
\hline \multirow[t]{2}{*}{$\mathrm{X} 3$} & 4.0 & 11.9 & 0.5 & 11.8 & 47.9 & 4.6 & 553 & 1458 & 50 & 2048 & 5403 & 106 & 181 & 10 & 199 & 273 & 99 \\
\hline & (7.2) & (9.5) & $(0.2)$ & (20.7) & (32.5) & (3.8) & (797) & (685) & (39) & (2525) & (2222) & (222) & (276) & (9) & (394) & (495) & $(152)$ \\
\hline \multirow[t]{2}{*}{ Y1 } & 332 & 964 & 51 & 851 & 3086 & 404 & 47084 & 126105 & 3183 & 194777 & $498507 \quad 68223$ & 2336 & 3888 & 360 & 12653 & 17869 & 5611 \\
\hline & (453) & $(222)$ & (28) & (1297) & (2026) & (317) & (72549) & (70391) & (2115) & $(222331)$ & (168467) (46633) & $(4418)$ & (5448) & (292) & $(21440)$ & (26198) & (9104) \\
\hline \multirow[t]{2}{*}{ Y2 } & 135 & 400 & 17 & 491 & 1159 & 357 & 29730 & 78283 & 2756 & 176313 & $463926 \quad 56474$ & 1855 & 3130 & 233 & 6714 & 8824 & 3867 \\
\hline & (236) & $(293)$ & (17) & (458) & (527) & (309) & (46983) & $(50820)$ & (1960) & $(213841)$ & (182044) (34571) & $(3508)$ & (4299) & (191) & $(11417)$ & (13290) & $(7684)$ \\
\hline \multirow[t]{2}{*}{$\mathrm{C} 1$} & 9.2 & 8.6 & 9.5 & 6.3 & 6.3 & 6.4 & 6.3 & 9.0 & 4.8 & 1.5 & 1.6 & 7.8 & 7.5 & 8.3 & 5.6 & 5.5 & 5.7 \\
\hline & (3.7) & (2.1) & (4.3) & (1.1) & (1.3) & (1.1) & $(4.5)$ & (6.9) & (1.5) & $(0.3)$ & $(0.1)$ & (1.3) & $(0.8)$ & (1.7) & $(0.7)$ & $(0.5)$ & $(0.8)$ \\
\hline \multirow[t]{2}{*}{$\mathrm{C} 2$} & 78.0 & 103.2 & 66.8 & 136.3 & 141.8 & 135.2 & 86.5 & 66.1 & 97.8 & 80.5 & 45.8 & 74.5 & 87.7 & 57.6 & 133.2 & 103.4 & 173.4 \\
\hline & (41.1) & $(46.5)$ & (35.6) & $(96.7)$ & (36.7) & (105.2) & $(59.8)$ & (68.6) & $(55.4)$ & $(34.4)$ & (8.8) (30.4) & $(53.2)$ & $(54.2)$ & $(48.0)$ & $(139.9)$ & (88.8) & $(183.3)$ \\
\hline \multirow[t]{2}{*}{$\mathrm{C} 3$} & 1.0 & 1.0 & 1.0 & 1.0 & 1.0 & 1.0 & 1.0 & 1.0 & 1.0 & 1.0 & 1.0 & 1.0 & 1.0 & 1.0 & 1.0 & 1.0 & 1.0 \\
\hline & $(0.0)$ & $(0.0)$ & $(0.0)$ & $(0.0)$ & $(0.0)$ & (0.0) & $(0.0)$ & $(0.0)$ & (0.0) & $(0.0)$ & $(0.0)$ & $(0.0)$ & $(0.0)$ & $(0.0)$ & $(0.0)$ & $(0.0)$ & $(0.0)$ \\
\hline \multirow[t]{2}{*}{ R1 } & 16.0 & 15.3 & 16.3 & 16.4 & 14.0 & 16.8 & 10.7 & 10.6 & 10.8 & 5.0 & 4.7 & 13.0 & 12.6 & 13.5 & 9.1 & 8.7 & 9.8 \\
\hline & (4.5) & (3.5) & (5.1) & (3.6) & (3.0) & (3.6) & (2.7) & (2.0) & (3.1) & $(0.4)$ & $(0.4)$ & (1.3) & $(1.0)$ & (1.4) & (1.0) & (0.6) & (1.1) \\
\hline \multirow[t]{2}{*}{ R2 } & 5.0 & 2.9 & 6.0 & 2.9 & 3.1 & 2.9 & 9.0 & 13.8 & & 3.0 & 3.4 & 15.8 & 14.8 & 17.2 & 10.4 & 9.5 & 11.5 \\
\hline & $(3.0)$ & (1.6) & (3.0) & (2.8) & (2.5) & (2.9) & (12.4) & (19.8) & (5.7) & $(0.6)$ & $(0.2)$ & (2.8) & (1.6) & (3.5) & (3.8) & (1.3) & (5.6) \\
\hline
\end{tabular}

$\mathrm{X} 1$ : total funding, X2: fixed assets, X3: personnel expenses, Y1: net loans, Y2: other earning assets,

$\mathrm{C} 1$ : total interest expense/X1, $\mathrm{C} 2$ : other operating expenses $/ \mathrm{X} 2, \mathrm{C} 3=1$,

$\mathrm{R} 1$ : interest income/Y1, R2: total non-interest operating income plus dividend/Y2

\section{Empirical Results}

\subsection{The efficiency of the regulated and state-dominated banking system}

Over the period 1995-2011, the three regulated and state-dominated banking systems generally achieved high efficiency levels, with an increasing trend (Figures 1-3).It is believed that these efficiency achievements could be the result of the positive effect of significant regulatory reforms which have been implemented in these banking sectors from the 1990s. Moreover, a number of points can be made about the results of Table 5.

First, the overall cost, revenue and profit efficiencies were, respectively, 0.91, 0.91 and 0.83 in Vietnam, 0.94, 0.96 and 0.93 in China, and 0.90, 0.91 and 0.81 in India. It can be seen that cost efficiency is virtually as high as revenue efficiency in these three banking systems. However, the profit efficiency of banks in Vietnam and India was lower than their cost and revenue efficiencies, implying that banks in Vietnam and India were efficient either at 


\section{Macrothink}

Asian Journal of Finance \& Accounting

ISSN 1946-052X

2015, Vol. 7, No. 2

managing costs or creating revenue. The profit efficiency of banks in China was similar to their cost and revenue efficiencies, implying that if a bank in China was competent at controlling costs, it was also competent at producing revenue and vice versa. Moreover, profit efficiency was equally driven by cost and revenue efficiencies.

Second, the mean technical and allocative efficiencies are respectively 0.95 and 0.96 in Vietnam; 0.98 and 0.96 in China; and 0.94 and 0.95 in India. This implies that banks in these countries were highly efficient in utilizing deposits, personnel and physical assets to produce loans and other earning assets (technical efficiency), and combining these bank inputs in an optimal way to reduce total cost while keeping the same amount of outputs (allocative efficiency). Also, cost efficiency of banks in these countries was almost equally driven by technical and allocative efficiencies.

Third, breaking the overall revenue into interest and non-interest revenue, we obtained the respective interest-revenue and non-interest revenue efficiencies of 0.89 and 0.56 in Vietnam, 0.94 and 0.83 in China, and 0.85 and 0.82 in India, implying that bank revenue efficiency in these countries was driven by interest revenue efficiency more than non-interest revenue efficiency, but with the greatest reliance on interest revenue efficiency in Vietnam, followed by China, then India.

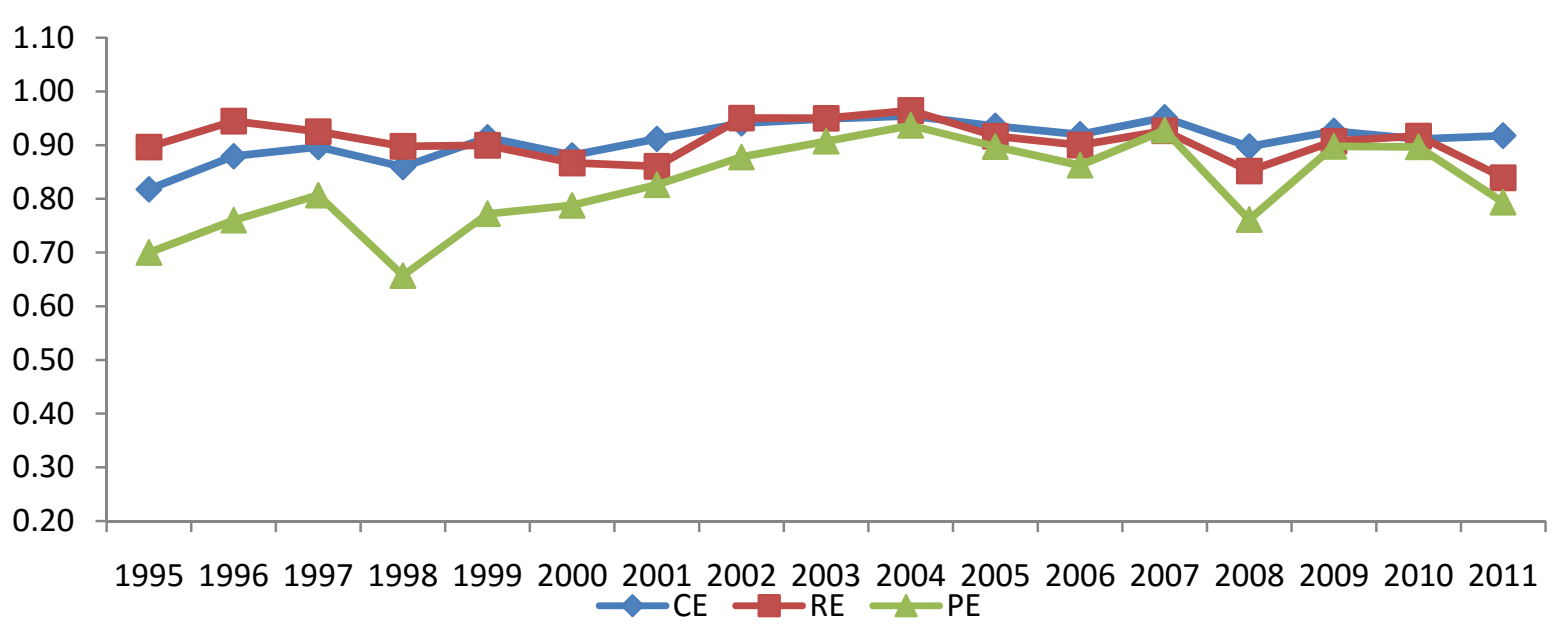

Figure 1. Weighted cost, revenue and profit efficiency of the Vietnamese banking system 


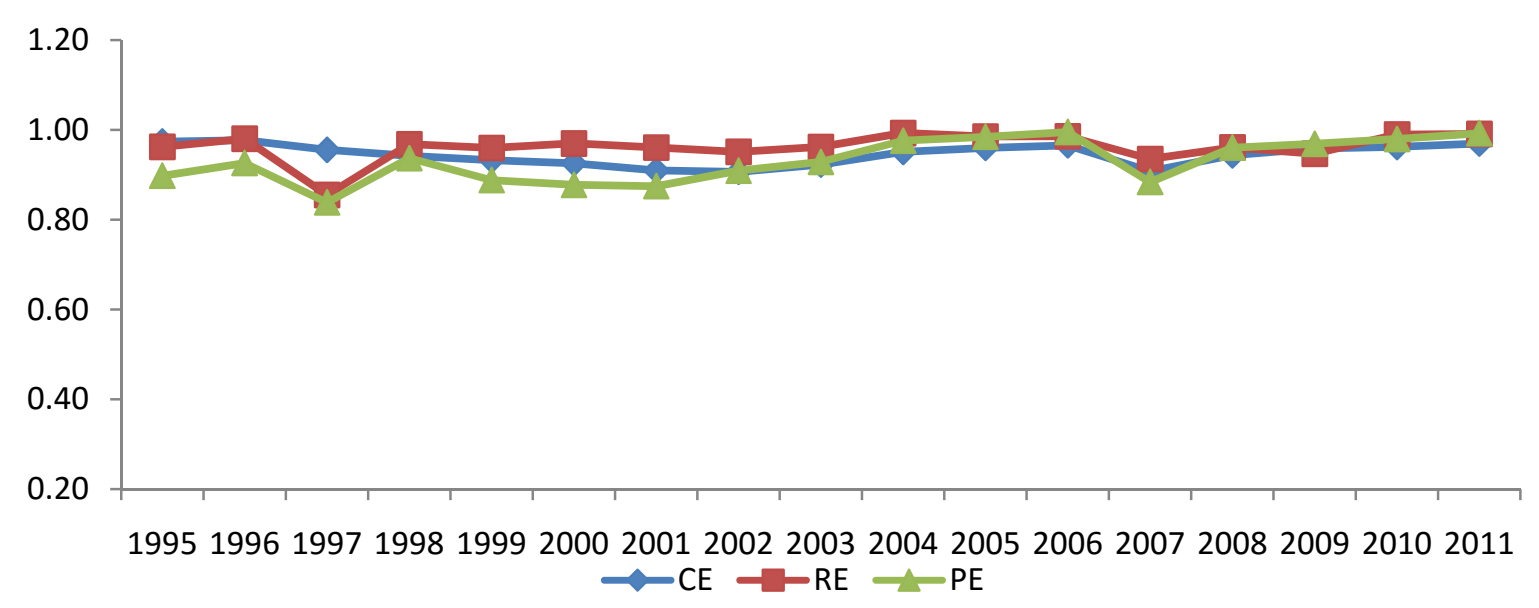

Figure 2. Weighted cost, revenue and profit efficiency of the Chinese banking system

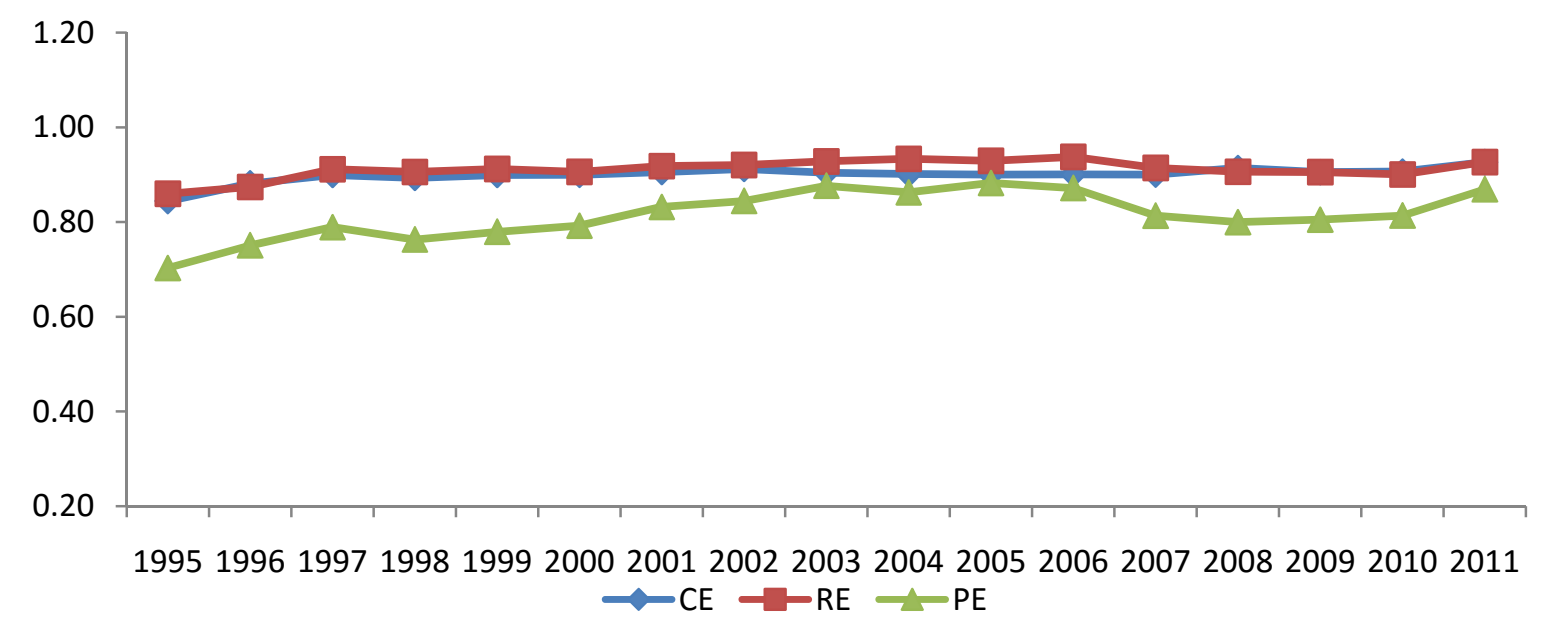

Figure 3. Weighted cost, revenue and profit efficiency of the Indian banking system 


\section{$\triangle$ Macrothink}

Table 5. The components of weighted cost, revenue and profit efficiency

\begin{tabular}{|c|c|c|c|c|c|c|c|c|c|c|c|c|c|c|c|c|c|c|c|c|c|}
\hline \multirow{2}{*}{ Year } & \multicolumn{7}{|c|}{ Vietnam } & \multicolumn{7}{|c|}{ China } & \multicolumn{7}{|c|}{ India } \\
\hline & $\mathrm{TE}$ & AE-Input & $\mathrm{CE}$ & $\mathrm{RE}$ & RE-I & RE-II & $\mathrm{PE}$ & $\mathrm{TE}$ & AE-Input & $\mathrm{CE}$ & RE & RE-I & RE-II & PE & $\mathrm{TE}$ & AE-Input & $\mathrm{CE}$ & RE & RE-I & RE-II & $\mathrm{PE}$ \\
\hline 1995 & 0.84 & 0.97 & 0.82 & 0.90 & 0.90 & 0.45 & 0.70 & & 0.99 & 0.97 & 0.96 & & & 0.90 & 0.88 & 0.96 & 0.84 & 0.86 & 0.69 & 0.82 & 0.70 \\
\hline 1996 & 0.95 & 0.93 & 0.88 & 0.94 & 0.94 & 0.48 & 0.76 & 0.99 & 0.98 & 0.98 & 0.98 & 0.96 & & 0.93 & 0.92 & 0.96 & 0.88 & 0.87 & 0.71 & 0.87 & 0.75 \\
\hline 1997 & 0.94 & 0.95 & 0.90 & 0.93 & 0.91 & 0.50 & 0.81 & 0.98 & 0.97 & 0.96 & 0.86 & 0.93 & 0.72 & 0.84 & 0.93 & 0.96 & 0.90 & 0.91 & 0.75 & 0.87 & 0.79 \\
\hline 1998 & 0.90 & 0.96 & 0.86 & 0.90 & 0.90 & 0.49 & 0.66 & 0.99 & 0.95 & 0.94 & 0.97 & 0.93 & 0.69 & 0.94 & 0.92 & 0.97 & 0.89 & 0.91 & 0.76 & 0.86 & 0.76 \\
\hline 1999 & 0.94 & 0.97 & 0.91 & 0.90 & 0.90 & 0.50 & 0.77 & 0.98 & 0.95 & 0.93 & 0.96 & 0.96 & 0.69 & 0.89 & 0.92 & 0.97 & 0.90 & 0.91 & 0.79 & 0.84 & 0.78 \\
\hline 2000 & 0.92 & 0.95 & 0.88 & 0.87 & 0.84 & 0.53 & 0.79 & 0.98 & 0.95 & 0.93 & 0.97 & 0.93 & 0.77 & 0.88 & 0.93 & 0.97 & 0.90 & 0.91 & 0.80 & 0.81 & 0.79 \\
\hline 2001 & 0.95 & 0.96 & 0.91 & 0.86 & 0.85 & 0.47 & 0.83 & 0.97 & 0.94 & 0.91 & 0.96 & 0.91 & 0.77 & 0.87 & 0.94 & 0.96 & 0.91 & 0.92 & 0.84 & 0.83 & 0.83 \\
\hline 2002 & 0.97 & 0.97 & 0.94 & 0.95 & 0.94 & 0.43 & 0.88 & 0.96 & 0.95 & 0.91 & 0.95 & 0.90 & 0.78 & 0.91 & 0.94 & 0.97 & 0.91 & 0.92 & 0.84 & 0.84 & 0.84 \\
\hline 2003 & 0.98 & 0.97 & 0.95 & 0.95 & 0.94 & 0.43 & 0.91 & 0.97 & 0.95 & 0.92 & 0.96 & 0.93 & 0.79 & 0.93 & 0.95 & 0.95 & 0.90 & 0.93 & 0.81 & 0.87 & 0.88 \\
\hline 2004 & 0.99 & 0.97 & 0.95 & 0.96 & 0.96 & 0.50 & 0.94 & 1.00 & 0.95 & 0.95 & 0.99 & 0.96 & 0.84 & 0.98 & 0.96 & 0.94 & 0.90 & 0.93 & 0.85 & 0.87 & 0.86 \\
\hline 2005 & 0.97 & 0.96 & 0.94 & 0.92 & 0.90 & 0.53 & 0.90 & 1.00 & 0.96 & 0.96 & 0.99 & 0.95 & 0.88 & 0.98 & 0.96 & 0.94 & 0.90 & 0.93 & 0.90 & 0.82 & 0.88 \\
\hline 2006 & 0.96 & 0.96 & 0.92 & 0.90 & 0.87 & 0.60 & 0.86 & 1.00 & 0.97 & 0.97 & 0.99 & 0.96 & 0.88 & 1.00 & 0.96 & 0.94 & 0.90 & 0.94 & 0.94 & 0.83 & 0.87 \\
\hline 2007 & 0.98 & 0.98 & 0.95 & 0.93 & 0.90 & 0.70 & 0.93 & 0.95 & 0.95 & 0.91 & 0.94 & 0.92 & 0.85 & 0.88 & 0.96 & 0.94 & 0.90 & 0.91 & 0.94 & 0.81 & 0.81 \\
\hline 2008 & 0.93 & 0.97 & 0.90 & 0.85 & 0.83 & 0.66 & 0.76 & 0.99 & 0.96 & 0.94 & 0.96 & 0.90 & 0.92 & 0.96 & 0.96 & 0.95 & 0.91 & 0.91 & 0.95 & 0.79 & 0.80 \\
\hline 2009 & 0.96 & 0.97 & 0.93 & 0.91 & 0.89 & 0.68 & 0.90 & 0.99 & 0.97 & 0.96 & 0.95 & 0.95 & 0.85 & 0.97 & 0.96 & 0.94 & 0.91 & 0.91 & 0.95 & 0.78 & 0.81 \\
\hline 2010 & 0.97 & 0.96 & 0.91 & 0.92 & 0.90 & 0.79 & 0.90 & 1.00 & 0.97 & 0.96 & 0.99 & 0.97 & 0.91 & 0.98 & 0.96 & 0.94 & 0.91 & 0.90 & 0.96 & 0.74 & 0.81 \\
\hline 2011 & 0.95 & 0.98 & 0.92 & 0.84 & 0.83 & 0.77 & 0.79 & 1.00 & 0.97 & 0.97 & 0.99 & 0.96 & 0.93 & 0.99 & 0.98 & 0.95 & 0.93 & 0.93 & 0.97 & 0.75 & 0.87 \\
\hline Mean & 0.95 & 0.96 & 0.91 & 0.91 & 0.89 & 0.56 & 0.83 & 0.98 & 0.96 & 0.94 & 0.96 & 0.94 & 0.83 & 0.93 & 0.94 & 0.95 & 0.90 & 0.91 & 0.85 & 0.82 & 0.81 \\
\hline
\end{tabular}

TE: technical efficiency; AE-Input: input allocative efficiency; CE: Cost efficiency; RE: Revenue efficiency; RE-I: interest revenue efficiency; RE-II: non-interest revenue efficiency; PE: profit efficiency

\subsection{The efficiency of state versus private banks}

We compared the performance of state against private banks by calculating the efficiency gap between them (t-test is used to test the significance of the gap and the results are all significant at 5\% level). If the efficiency gap was positive, we deduced that state banks were more efficient than private banks. A number of points can be made about the results of Table 6 . The results highlight that the respective mean cost, revenue and profit efficiency gaps for the whole analysis period are $0.13,0.17$ and 0.24 for the Vietnamese banking system; 0.07, 0.05 and 0.09 for the Chinese banking system; and $0.09,0.01$ and 0.03 for the Indian banking system. These results suggest that in the regulated and state-dominated banking systems, state banks were more cost, revenue and profit-efficient than private banks. This could be explained by better governance due to longer operations, and more benefits on the cost side from the government due to state-driven banking systems. For example, state banks may not pay full market rent for offices; they may pay below-market rates on deposits from government-owned non-financial firms and enjoy benefits resulting from other government protection. Further reasons are lower mobilizing costs due to being thought safer and more strategically important lending projects due to bigger capacity. However, these efficiency gaps have generally declined over the analysis period. This could be explained by the gradual relaxation of subsidies of the state to state banks within the context of banking deregulation. 
This has enabled private banks to gain market share at the expense of state banks, and then improve their efficiency at a greater speed than state banks over the years.

Table 6. The efficiency of state against private banks

\begin{tabular}{cccc|ccc|ccc}
\hline & & \multicolumn{3}{c}{ Vietnam } & & \multicolumn{3}{c}{ China } & \multicolumn{3}{c}{ India } \\
Year & CE gap & RE gap & PE gap & CE gap & RE gap & PE gap & CE gap & RE gap & PE gap \\
\hline 1995 & 0.01 & 0.13 & -0.13 & 0.06 & 0.06 & 0.04 & 0.12 & 0.19 & 0.25 \\
1996 & 0.14 & 0.22 & 0.20 & 0.09 & 0.06 & 0.12 & 0.11 & 0.09 & 0.17 \\
1997 & 0.22 & 0.17 & 0.35 & 0.09 & 0.00 & 0.02 & 0.07 & 0.03 & 0.10 \\
1998 & 0.21 & 0.31 & 0.34 & 0.11 & 0.10 & 0.21 & 0.06 & 0.03 & 0.11 \\
1999 & 0.19 & 0.17 & 0.38 & 0.22 & 0.17 & 0.30 & 0.06 & 0.02 & 0.04 \\
2000 & 0.18 & 0.20 & 0.34 & 0.20 & 0.15 & 0.26 & 0.08 & 0.02 & 0.05 \\
2001 & 0.15 & 0.13 & 0.32 & 0.18 & 0.14 & 0.23 & 0.10 & -0.03 & -0.06 \\
2002 & 0.16 & 0.21 & 0.30 & 0.07 & 0.05 & 0.10 & 0.13 & 0.01 & 0.09 \\
2003 & 0.15 & 0.17 & 0.29 & 0.00 & -0.01 & -0.01 & 0.16 & 0.00 & 0.00 \\
2004 & 0.12 & 0.17 & 0.27 & 0.05 & 0.02 & 0.06 & 0.20 & -0.01 & 0.13 \\
2005 & 0.12 & 0.15 & 0.24 & 0.04 & 0.01 & 0.05 & 0.15 & -0.05 & -0.06 \\
2006 & 0.12 & 0.17 & 0.24 & 0.02 & 0.03 & 0.03 & 0.12 & -0.04 & -0.07 \\
2007 & 0.09 & 0.14 & 0.12 & -0.05 & -0.02 & -0.05 & 0.08 & -0.05 & -0.10 \\
2008 & 0.07 & 0.20 & 0.25 & 0.03 & 0.04 & 0.11 & 0.03 & -0.02 & -0.08 \\
2009 & 0.08 & 0.14 & 0.12 & 0.03 & 0.00 & 0.05 & 0.02 & -0.02 & -0.04 \\
2010 & 0.12 & 0.08 & 0.17 & 0.00 & 0.00 & 0.02 & 0.08 & -0.01 & -0.01 \\
\hline Mean & 0.13 & 0.17 & 0.24 & 0.07 & 0.05 & 0.09 & 0.09 & 0.01 & 0.03 \\
\hline
\end{tabular}

CE: Cost efficiency; RE: Revenue efficiency; PE: profit efficiency

There were some differences, nonetheless, in the efficiency behaviour of the three regulated and state-dominated banking systems. These differences could have been partly brought about by variation in the reform programs and reform speed. At first, state banks performed better than private banks in Vietnam and China in cost, revenue and profit efficiencies in each year of the analysis period, whereas state banks in India were well ahead of private banks in only cost efficiency. State banks in India operated at the same level or were surpassed by private banks in revenue and profit efficiencies from 2000. We also examined the most efficient banks and the least efficient banks in these three regulated and state-dominated banking systems. An interesting pattern emerged that the five most efficient banks comprise both state and private banks, while the five least efficient banks included only private banks.

\subsection{The stability of the regulated and state-dominated banking system}

We created a 'Difference' variable by subtracting the mean efficiency score of the crisis period from that of the pre-crisis period. We hypothesized that if the efficiency difference was relatively positive, the mean efficiency score of the pre-crisis period is relatively larger than that of the crisis period, implying that bank efficiency may be hit by the crisis; otherwise 
banks are resilient in the crisis period. We selected 1995-1996, 1997-1999, 2004-2006 and 2007-2009 as pre-AFC, AFC, pre-GFC and GFC period, respectively.

A number of points can be made about the results in Table 7-9. First, the differences between pre-AFC and AFC periods in cost, revenue and profit efficiency are 0.04, 0.02 and 0.15 for Vietnamese banks; $0.05,0.05$ and 0.06 for Chinese banks, and $-0.06,-0.09$ and -0.10 for Indian banks (these differences are significant at 5\% level when using t-test). The results suggest that Vietnamese and Chinese banks appear to have been slightly hit by the AFC, while Indian banks appear to have been resilient throughout this crisis. Second, the respective differences between pre-GFC and GFC in cost, revenue, and profit efficiencies are - $0.02,0.01$ and -0.01 for the Vietnamese banking system, $0.00,0.04$ and 0.03 for the Chinese banking system, and $0.01,0.02$ and 0.08 for the Indian banking system. This implies that the Vietnamese banking system appears to have been resilient in the GFC, while the Chinese and Indian banking systems appear to have been slightly hit by the GFC. Third, the efficiency differences between pre-AFC and AFC periods for state banks are smaller than for private banks, while those between pre-GFC and GFC periods for state banks are larger than for private banks. This suggests that state banks were better than private banks in coping with the AFC, but worse in facing the GFC. This could be because the government, as a WTO commitment, has relaxed the subsidies to state banks in recent years. Therefore, the efficiency deterioration of the banking system in the GFC period was mainly caused by state banks, due to the government's relaxation of subsidies to state banks rather than the GFC impact.

Table 7. The effect of the AFC and GFC on banks in Vietnam

\begin{tabular}{|c|c|c|c|c|c|c|c|c|c|c|c|c|c|}
\hline \multirow{2}{*}{\multicolumn{2}{|c|}{ Crisis Efficiency }} & \multicolumn{4}{|c|}{ State-owned banks } & \multicolumn{4}{|c|}{ Joint-stock banks } & \multicolumn{4}{|c|}{ The Vietnamese banking system } \\
\hline & & No. of obs & Pre-crisis & Crisis & Difference & No. of obs & Pre-crisis & Crisis & Difference & No. of obs & Pre-crisis & Crisis & Difference \\
\hline \multirow{3}{*}{$\mathrm{AFC}$} & $\mathrm{CE}$ & 4.00 & 0.87 & 0.92 & -0.04 & 7.00 & 0.83 & 0.73 & 0.09 & 11.00 & 0.84 & 0.80 & 0.04 \\
\hline & $\mathrm{RE}$ & 4.00 & 0.95 & 0.93 & 0.01 & 7.00 & 0.75 & 0.72 & 0.03 & 11.00 & 0.82 & 0.80 & 0.02 \\
\hline & $\mathrm{PE}$ & 4.00 & 0.77 & 0.80 & -0.03 & 7.00 & 0.67 & 0.42 & 0.25 & 11.00 & 0.71 & 0.56 & 0.15 \\
\hline \multirow{3}{*}{$\mathrm{GFC}$} & $\mathrm{CE}$ & 5.00 & 0.94 & 0.92 & 0.02 & 18.00 & 0.85 & 0.88 & -0.03 & 23.00 & 0.87 & 0.89 & -0.02 \\
\hline & $\mathrm{RE}$ & 5.00 & 0.93 & 0.91 & 0.02 & 18.00 & 0.83 & 0.81 & 0.01 & 23.00 & 0.85 & 0.83 & 0.01 \\
\hline & PE & 5.00 & 0.88 & 0.82 & 0.07 & 18.00 & 0.72 & 0.76 & -0.04 & 23.00 & 0.75 & 0.77 & -0.01 \\
\hline
\end{tabular}




\section{$\triangle$ Macrothink}

Table 8. The effect of the AFC and GFC on banks in China

\begin{tabular}{cc|cccc|cccc|cccc}
\hline \multirow{2}{*}{ Crisis Efficiency } & \multicolumn{4}{|c|}{ Equitized banks } & \multicolumn{4}{c|}{ Joint-stock banks } & \multicolumn{4}{c}{ The Chinese banking system } \\
& & No. of obs & Pre-crisis & Crisis & Difference & No. of obs & Pre-crisis & Crisis & Difference & No. of obs & Pre-crisis & Crisis & Difference \\
\hline \multirow{3}{*}{ AFC } & CE & 4 & 0.98 & 0.96 & 0.01 & 8 & 0.89 & 0.82 & 0.07 & 12 & 0.92 & 0.86 & 0.05 \\
& RE & 4 & 0.97 & 0.94 & 0.02 & 8 & 0.92 & 0.85 & 0.07 & 12 & 0.94 & 0.88 & 0.05 \\
& PE & 4 & 0.90 & 0.90 & 0.00 & 8 & 0.81 & 0.72 & 0.09 & 12 & 0.84 & 0.78 & 0.06 \\
\hline \multirow{3}{*}{ GFC } & CE & 5 & 0.94 & 0.92 & 0.02 & 10 & 0.92 & 0.93 & -0.01 & 15 & 0.93 & 0.93 & 0.00 \\
& RE & 5 & 0.98 & 0.94 & 0.04 & 10 & 0.94 & 0.91 & 0.03 & 15 & 0.96 & 0.92 & 0.04 \\
& PE & 5 & 0.99 & 0.95 & 0.03 & 10 & 0.97 & 0.95 & 0.02 & 15 & 0.98 & 0.95 & 0.03 \\
\hline
\end{tabular}

Table 9. The effect of the AFC and GFC on banks in India

\begin{tabular}{|c|c|c|c|c|c|c|c|c|c|c|c|c|c|}
\hline \multirow{2}{*}{ Crisis } & \multirow{2}{*}{ Efficiency } & \multicolumn{4}{|c|}{ Public banks } & \multicolumn{4}{|c|}{ Private banks } & \multicolumn{4}{|c|}{ The Indian banking system } \\
\hline & & No. of obs & Pre-crisis & Crisis & Difference & No. of obs & Pre-crisis & Crisis & Difference & No. of obs & Pre-crisis & Crisis & Difference \\
\hline \multirow{3}{*}{$\mathrm{AFC}$} & $\mathrm{CE}$ & 28 & 0.83 & 0.88 & -0.05 & 22 & 0.79 & 0.87 & -0.08 & 50 & 0.81 & 0.88 & -0.06 \\
\hline & $\mathrm{RE}$ & 28 & 0.85 & 0.89 & -0.04 & 22 & 0.75 & 0.90 & -0.15 & 50 & 0.80 & 0.89 & -0.09 \\
\hline & $\mathrm{PE}$ & 28 & 0.68 & 0.74 & -0.06 & 22 & 0.67 & 0.73 & -0.06 & 50 & 0.63 & 0.73 & -0.10 \\
\hline \multirow{3}{*}{ GFC } & $\mathrm{CE}$ & 26 & 0.91 & 0.89 & 0.02 & 19 & 0.83 & 0.83 & 0.00 & 45 & 0.87 & 0.86 & 0.01 \\
\hline & $\mathrm{RE}$ & 26 & 0.91 & 0.87 & 0.03 & 19 & 0.90 & 0.89 & 0.01 & 45 & 0.91 & 0.88 & 0.02 \\
\hline & $\mathrm{PE}$ & 26 & 0.83 & 0.72 & 0.10 & 19 & 0.79 & 0.74 & 0.04 & 45 & 0.81 & 0.73 & 0.08 \\
\hline
\end{tabular}

\subsection{Robust check}

To have a robust check of the findings on banking-system efficiency trend and efficiency gap between state and private banks in section 4.1 and 4.2, we employ Tobit regression (because the dependent variable is censored at 0 and 1) where dependent variables are the efficiency scores and independent variables are bank-specific characteristics, ownership, reform and environmental factors. We used a variable 'Time' which respectively equals 1 through to 17 for years 1995-2011 to capture the efficiency trend over the analysis period resulted from banking reforms; a dummy variable 'SOB' which equals 1 for state banks and 0 otherwise to characterise the efficiency of state banks relative to private banks and an interaction variable 'Time $\mathrm{x}$ SOB' of variables 'Time' and 'SOB' to capture the trend of efficiency gap between state and private banks from 1995 to 2011.

Table 10 displays the impact of bank-specific characteristics, ownership, reform and economic performance on bank efficiency. It can be seen that the coefficients on the time trend ('Time') are significantly positive for all three banking systems, confirming that cost, revenue and profit efficiencies of the regulated and state-dominated banking system experiences an upward trend over the period 1995-2011. Moreover, the coefficients on state ownership (dummy variable 'SOB') are all significantly positive (except that coefficient on state ownership for Vietnamese banks in profit efficiency case is positive but not significant). This suggests that state banks of the regulated and state-dominated banking system are more efficient than private banks. In addition, the coefficients of interaction between time trend and state ownership ('Time $\mathrm{x}$ SOB') are all significantly negative, confirming that the reforms towards liberalisation have narrowed the efficiency gap between state and private banks over the analysis period. In brief, these findings on the efficiency behaviour of the three regulated 
and state-dominated banking systems support the results obtained by calculating raw efficiency scores in section 4.1 and 4.2. Table 10 also provides information on other variables; however, we are not explaining their empirical relationship with bank efficiency as these variables were control variables in the model.

Table 10. Tobit regression of efficiency score on other factors

\begin{tabular}{|c|c|c|c|c|c|c|c|c|c|}
\hline & \multicolumn{3}{|c|}{ Vietnam } & \multicolumn{3}{|c|}{ China } & \multicolumn{3}{|c|}{ India } \\
\hline & $\mathrm{CE}$ & $\mathrm{RE}$ & PE & $\mathrm{CE}$ & RE & PE & $\mathrm{CE}$ & $\mathrm{RE}$ & PE \\
\hline Number of obs & 365 & 365 & 2365 & 289 & 289 & 289 & 901 & 901 & 901 \\
\hline Cons & $\begin{array}{c}0.9487^{* * *} \\
(7.95)\end{array}$ & $\begin{array}{c}1.2466^{* * * *} \\
(7.78)\end{array}$ & $\begin{array}{c}1.3944^{* * *} \\
(4.36)\end{array}$ & $\begin{array}{c}1.9267^{* * * *} \\
(6.60)\end{array}$ & $\begin{array}{c}1.3742^{* * *} \\
(4.60)\end{array}$ & $\begin{array}{c}1.9156^{* * * *} \\
(2.57)\end{array}$ & $\begin{array}{c}1.7362 * * * \\
(25.05)\end{array}$ & $\begin{array}{c}1.4263^{* * *} \\
(18.14)\end{array}$ & $\begin{array}{c}2.0458^{* * *} \\
(10.60)\end{array}$ \\
\hline SOB & $\begin{array}{c}0.1408^{* * *} \\
(2.91)\end{array}$ & $\begin{array}{c}0.2225^{* * *} \\
(3.59)\end{array}$ & $\begin{array}{l}0.1810 \\
(1.48)\end{array}$ & $\begin{array}{c}0.1217^{* * *} \\
(3.53)\end{array}$ & $\begin{array}{c}0.1670^{* * *} \\
(4.82)\end{array}$ & $\begin{array}{c}0.3271^{* * * *} \\
(3.71)\end{array}$ & $\begin{array}{c}0.1303^{* * *} \\
(9.88)\end{array}$ & $\begin{array}{c}0.0960^{* * * *} \\
(6.44)\end{array}$ & $\begin{array}{c}0.1948^{* * *} \\
(5.47)\end{array}$ \\
\hline ETA & $\begin{array}{l}0.0011 \\
(1.10)\end{array}$ & $\begin{array}{l}0.0015 \\
(1.07)\end{array}$ & $\begin{array}{c}0.0160 * * * \\
(5.19)\end{array}$ & $\begin{array}{c}0.0040 * * \\
(2.14)\end{array}$ & $\begin{array}{c}0.0055^{* * *} \\
(2.84)\end{array}$ & $\begin{array}{c}0.0140 * * * \\
(2.96)\end{array}$ & $\begin{array}{c}0.0024 * * * \\
(2.51)\end{array}$ & $\begin{array}{c}0.0040 * * * \\
(3.57)\end{array}$ & $\begin{array}{c}0.0236 * * * \\
(7.93)\end{array}$ \\
\hline Loans_deposit & $\begin{array}{l}0.0001 \\
(0.58)\end{array}$ & $\begin{array}{c}0.0013 * * * \\
(4.44)\end{array}$ & $\begin{array}{c}0.0015^{* * *} \\
(2.63)\end{array}$ & $\begin{array}{c}0.0009^{*} \\
(1.87)\end{array}$ & $\begin{array}{l}0.0006 \\
(1.27)\end{array}$ & $\begin{array}{l}-0.0001 \\
(-0.07)\end{array}$ & $\begin{array}{c}0.00005^{* * *} \\
(3.06)\end{array}$ & $\begin{array}{c}0.0001 * * * \\
(2.66)\end{array}$ & $\begin{array}{l}0.0001 \\
(1.60)\end{array}$ \\
\hline Size & $\begin{array}{c}-0.1451 * * * \\
(-3.46)\end{array}$ & $\begin{array}{c}-0.2652 * * * \\
(-4.74)\end{array}$ & $\begin{array}{c}-0.5974 * * * \\
(-5.28)\end{array}$ & $\begin{array}{c}-0.2625 * * * \\
(-4.78)\end{array}$ & $\begin{array}{c}-0.1202 * * \\
(-2.15)\end{array}$ & $\begin{array}{c}-0.2720 * * \\
(-1.95)\end{array}$ & $\begin{array}{c}-0.2220 * * * \\
(-13.13)\end{array}$ & $\begin{array}{c}-0.1532 * * * \\
(-7.98)\end{array}$ & $\begin{array}{c}-0.3780 * * * \\
(-7.97)\end{array}$ \\
\hline Size square & $\begin{array}{c}0.0135 * * * \\
(3.87)\end{array}$ & $\begin{array}{c}0.0236^{* * *} \\
(5.14)\end{array}$ & $\begin{array}{c}0.0583 * * * \\
(6.25)\end{array}$ & $\begin{array}{c}0.0131 * * * \\
(5.04)\end{array}$ & $\begin{array}{c}0.0050 * \\
(1.90)\end{array}$ & $\begin{array}{c}0.0118^{*} \\
(1.80)\end{array}$ & $\begin{array}{c}0.0123 * * * \\
(12.38)\end{array}$ & $\begin{array}{c}0.0092 * * * \\
(8.11)\end{array}$ & $\begin{array}{c}0.0227 * * * \\
(8.13)\end{array}$ \\
\hline Gdp_growth & $\begin{array}{c}0.0172 * * * \\
(3.14)\end{array}$ & $\begin{array}{c}0.0106 \\
(1.5)\end{array}$ & $\begin{array}{c}0.0448 * * * \\
(3.23)\end{array}$ & $\begin{array}{c}0.0105^{* * *} \\
(3.17)\end{array}$ & $\begin{array}{c}0.0082 * * * \\
(2.52)\end{array}$ & $\begin{array}{c}0.0210^{* * *} \\
(2.58)\end{array}$ & $\begin{array}{c}-0.0038 * * * \\
(-3.04)\end{array}$ & $\begin{array}{c}-0.0045^{* * *} \\
(-3.18)\end{array}$ & $\begin{array}{c}-0.0070 * * \\
(-2.10)\end{array}$ \\
\hline Time & $\begin{array}{c}0.0114 * * * \\
(4.53)\end{array}$ & $\begin{array}{l}0.0053 \\
(1.58)\end{array}$ & $\begin{array}{c}0.0125^{*} \\
(1.90)\end{array}$ & $\begin{array}{c}0.0076^{* * *} \\
(4.05)\end{array}$ & $\begin{array}{c}0.0116^{* * *} \\
(6.02)\end{array}$ & $\begin{array}{c}0.0262 * * * \\
(5.31)\end{array}$ & $\begin{array}{c}0.0065^{* * *} \\
(6.76)\end{array}$ & $\begin{array}{c}0.0080^{* * *} \\
(7.33)\end{array}$ & $\begin{array}{c}0.0119 * * * \\
(4.61)\end{array}$ \\
\hline TimexSOB & $\begin{array}{c}-0.0099 * * * \\
(-2.58)\end{array}$ & $\begin{array}{c}-0.0166^{* * *} \\
(-3.41)\end{array}$ & $\begin{array}{c}-0.0250^{* * *} \\
(-2.6)\end{array}$ & $\begin{array}{c}-0.0169^{* * *} \\
(-5.68)\end{array}$ & $\begin{array}{c}-0.0107^{* * * *} \\
(-3.59)\end{array}$ & $\begin{array}{c}-0.0196^{* * * *} \\
(-2.58)\end{array}$ & $\begin{array}{c}-0.0037^{* * *} \\
(-3.20)\end{array}$ & $\begin{array}{c}-0.0078^{* * *} \\
(-6.08)\end{array}$ & $\begin{array}{c}-0.0118^{* * *} \\
(-3.87)\end{array}$ \\
\hline
\end{tabular}

CE: Cost efficiency; RE: Revenue efficiency; PE: profit efficiency

SOB: dummy variable which equals 1 for state banks and 0 otherwise; ETA: equity divided by total assets; Loans_deposit: ratio of loans to deposits; Size: natural logarithm of total assets; Gdp_growth: annual GDP growth; Time: respectively equals 1-17 for years 1995-2011; Time x SOB: interaction variable of 'Time' and 'SOB'

To the best of our knowledge, this is the first study comparing the efficiency behaviour across the banking systems of Vietnam, China and India, so we just compared our findings with the existing literature in regards to efficiency levels and trends of individual countries. It appears that for Vietnamese banks, our finding is basically in line with that of Vu and Turnell (2010) for cost efficiency levels and trends as well as Gardener et al. (2011)'s finding for more cost-efficient state banks than private banks.For Chinese banks, the finding is similar to that of Jiang et al. (2013) for cost and profit efficiency levels,Berger et al. (2009) for cost efficiency level, and Chen et al. (2005) and Berger et al. (2009) for cost efficiency of state banks relative to private banks. For Indian banks, the finding supports Wanniarachchige and Suzuki (2011)'s study for cost and revenue efficiency levels as well as gaps between state and private banks, Ray and Das (2010) and Tabak and Langsch Tecles (2010)'s findings for cost and profit efficiency levels and gaps between state and private banks, andPerera et al. (2007) for being resilient in the AFC period. 


\section{Conclusion}

This study investigated the cost, revenue and profit efficiency levels and trends of banks in Vietnam, China and India, explored the drivers of these efficiencies, compared the efficiency of state-owned banks against private banks, and examined the impact of AFC and GFC on the efficiency of these banks over the period of 1995-2011. Using the DEA Window Analysis, the first finding was that the banking systems of Vietnam, China and India achieved high efficiency levels, with increasing efficiency trends over the analysis period. Cost efficiency was equally driven by technical and allocative efficiencies, while revenue efficiency was driven more by efficiency from interest income than from non-interest income, and profit efficiency was equally driven by cost and revenue efficiency. The second finding was that state banks were more efficient than private banks, but the efficiency gap has become smaller towards the end of the analysis period. The five most efficient banks, moreover, comprised both state and private banks, while the five least efficient banks were only private banks. Thirdly, compared with private banks, state banks appear to have been better at coping with the AFC, but worse at facing the GFC. Fourthly, the Vietnamese and Chinese banking systems appear to have been slightly hit by the AFC, while the Chinese and Indian banking systems experienced efficiency deterioration during the GFC period.

Some differences in efficiency behaviour among these regulated and state-dominated banking systems were also observed. Banks in Vietnam and India have been efficient in either managing costs or creating revenue, while banks in China have been good at both. The revenue efficiency of banks in Vietnam was found to rely most on interest-revenue efficiency, followed by China and then India. In each year analysed, state banks in Vietnam and China performed better than private banks in cost, revenue and profit efficiency, whereas state banks in India were well ahead of private banks only in cost efficiency. State banks in India operated either at the same level or were surpassed by private banks from 2000 on. These differences could be partly explained by differences in the programs and speed of banking reforms.

\section{References}

Altunbas, Y., Evans, L., \& Molyneux, P. (2001). Bank ownership and efficiency. Journal of Money, Credit and Banking, 33(4), 926-954.

Avkiran, N. K. (2004). Decomposing technical efficiency and window analysis. Studies in Economics and Finance, 22(1), 61-91. http://dx.doi.org/10.1108/eb043383

Banker, R. D., Charnes, A., \& Cooper, W. W. (1984). Some models for estimating technical and scale inefficiencies in data envelopment analysis. Management science, 30(9), 1078-1092. http://dx.doi.org/10.1287/mnsc.30.9.1078

Berger, A. N., Hasan, I., \& Zhou, M. (2009). Bank ownership and efficiency in China: What will happen in the world's largest nation? Journal of banking \& finance, 33(1), 113-130. http://dx.doi.org/10.2139/ssrn.924246 
Charnes, A., Clark, C. T., Cooper, W., \& Golany, B. (1984). A developmental study of data envelopment analysis in measuring the efficiency of maintenance units in the US air forces. Annals of Operations Research, 2(1), 95-112. http://dx.doi.org/10.1007/bf01874734

Charnes, A., \& Cooper, W. W. (1984). Preface to topics in data envelopment analysis. Annals of Operations Research, 2(1), 59-94. http://dx.doi.org/10.1007/bf01874733

Chen, X., Skully, M., \& Brown, K. (2005). Banking efficiency in China: Application of DEA to pre- and post-deregulation eras: 1993-2000. China Economic Review, 16(3), 229-245. http://dx.doi.org/10.1016/j.chieco.2005.02.001

Cooper, W. W., \& Seiford, L. M. (2000). Data envelopment analysis: A comprehensive text with models, Applications, references, and DEA-Solver Software: Kluwer academic publishers, Boston.

Cooper, W. W., Seiford, L. M., \& Tone, K. (2007). Data envelopment analysis: a comprehensive text with models, applications, references and DEA-solver software: Springer Science+ Business Media.

Drake, L., Hall, M. J. B., \& Simper, R. (2009). Bank modelling methodologies: A comparative non-parametric analysis of efficiency in the Japanese banking sector. Journal of International Financial Markets, Institutions and Money, 19(1), 1-15. http://dx.doi.org/10.1016/j.intfin.2007.05.002

Färe, R., \& Grosskopf, S. (1997). Profit efficiency, Farrell decompositions and the Mahler inequality. Economics Letters, 283-287. http://dx.doi.org/10.1016/s0165-1765(97)00234-6

Färe, R., Grosskopf, S., \& Weber, W. L. (2004). The effect of risk-based capital requirements on profit efficiency in banking. Applied economics, 36(15), 1731-1743. http://dx.doi.org/10.1080/0003684042000218525

Jiang, C., Yao, S., \& Feng, G. (2013). Bank Ownership, Privatization, and Performance: Evidence from a Transition Country. Journal of banking \& finance, 37(9), 3364-3372. http://dx.doi.org/10.1016/j.jbankfin.2013.05.009

Koetter, M. (2006). Measurement Matters-Alternative Input Price Proxies for Bank Efficiency Analyses. Journal of Financial Services Research, 30(2), 199-227. http://dx.doi.org/10.1007/s10693-006-0018-4

Malmquist, S. (1953). Index numbers and indifference surfaces. Trabajos de Estadistica y de Investigacion Operativa, 4(2), 209-242. http://dx.doi.org/10.1007/bf03006863

Maudos, J., Pastor, J. M., Perez, F., \& Quesada, J. (2002). Cost and profit efficiency in European banks. Journal of International Financial Markets, Institutions and Money, 12(1), 33-58. http://dx.doi.org/10.1016/s1042-4431(01)00051-8 
Moffat, B. D., \& Valadkhani, A. (2011). Efficiency of Botswana's financial institutions: a data envelopment analysis. Applied Economics Letters, 18(7), 697-702. http://dx.doi.org/10.1080/13504851.2010.491456

Perera, S., Skully, M., \& Wickramanayake, J. (2007). Cost Efficiency in South Asian Banking: The Impact of Bank Size, State Ownership and Stock Exchange Listings. International Review of Finance, $7(1,2), \quad 35-60$. http://dx.doi.org/10.1111/j.1468-2443.2007.00067.x

Ray, S. C., \& Das, A. (2010). Distribution of cost and profit efficiency: Evidence from Indian banking. European journal of operational research, 201(1), 297-307. http://dx.doi.org/10.1016/j.ejor.2009.02.030

Tabak, B. M., \& Langsch Tecles, P. (2010). Estimating a Bayesian stochastic frontier for the Indian banking system. International Journal of Production Economics, 125(1), 96-110. http://dx.doi.org/10.1016/j.ijpe.2010.01.008

Vu, H. T., \& Turnell, S. (2010). Cost efficiency of the banking sector in Vietnam: A Bayesian stochastic frontier approach with regularity constraints. Asian Economic Journal, 24(2), 115-139. http://dx.doi.org/10.1111/j.1467-8381.2010.02035.x

Wanniarachchige, M. K., \& Suzuki, Y. (2011). How Does Ownership Affect Bank Performance?-The Case Of Indian Commercial Banks. International Business \& Economics Research Journal (IBER), 10(3), 71-82.

Zhu, J. (2000). Multi-factor performance measure model with an application to Fortune 500 companies. European journal of operational research, 123(1), 105-124. Retrieved from http://www.sciencedirect.com/science/article/pii/S037722179900096X 